\title{
Water Stress and Crop Level Interactions in Relation to Nectarine Yield, Fruit Size Distribution, and Water Potentials
}

\author{
A. Naor \\ Golan Research Institute, P.O. Box 97 Kazrin 12900, Israel
}

I. Klein

Institute of Horticulture, ARO, The Volcani Center, Bet Dagan 50250, Israel

H. Hupert, Y. Grinblat, and M. Peres

Extension Service, Ministry of Agriculture and Rural Development, Kiriat Shemona, 10200, Israel

\author{
A. Kaufman \\ Upper Galilee Agriculture Company Ltd, Kiriat Shemona, 10200, Israel
}

AdDitIONAL INDEX wORDS. nectarine, crop load, fruit size distribution, water potential, water stress, irrigation

\begin{abstract}
The interactions between irrigation and crop level with respect to fruit size distribution and soil and stem water potentials were investigated in a nectarine (Prunus persica (L.) Batsch. 'Fairlane') orchard located in a semiarid zone. Irrigation treatments during stage III of fruit growth ranged from 0.62 to 1.29 of potential evapotranspiration (ETp). Fruit were hand thinned to a wide range of fruit levels (200 to 1200 fruit/tree in the 555 -tree/ha orchard). Total yield did not increase with increasing irrigation rate above $0.92 \mathrm{ETp}$ in 1996 and maximum yield was found at 1.06 ETp in 1997. Fruit size distribution was shifted towards larger fruit with increasing irrigation level and with decreasing crop level. The two highest irrigation treatments had similar midday stem water potentials. Our findings indicate that highest yields and highest water use efficiency (yield/water consumption) are not always related to minimum water stress. Total yield and large fruit yield were highly and better correlated with midday stem water potential than with soil water potential. This confirms other reports that midday stem water potential is an accurate indicator of tree water stress and may have utility in irrigation scheduling.
\end{abstract}

Fruit size is a major criterion of nectarine fruit quality. Since fruit size is affected by crop load and water deficit (Berman and DeJong, 1996; Naor et al., 1997b), it is of interest to optimize crop level and water availability, in order to maximize the number of large fruit.

Peach crop yield can account for $65 \%$ to $70 \%$ of total tree annual dry matter production (Chalmers and van den Ende, 1975). Peach and nectarine fruit size decreases with increasing crop load (Berman and DeJong, 1996; Blanco et al., 1995; Rowe and Johnson, 1992; Tukey and Einset, 1938), probably because of the limited availability of assimilates. Compared with nonfruiting trees, fruiting nectarine trees often have greater stomatal conductance (Chalmers et al., 1983; DeJong, 1986a, 1986b) and higher assimilation rates (Chalmers et al., 1975; Crews et al., 1975; DeJong, 1986b), probably partially to compensate for the increased assimilate demand. The higher stomatal conductance of fruiting trees is accompanied by higher leaf and fruit transpiration rates (Chalmers et al., 1983), and lower midday (Chalmers et al., 1983; DeJong 1986a) and night (Chalmers and Wilson, 1978) leaf water potential compared with nonfruiting trees. Assimilation rate and midday stem water potential of stressed peach trees, decreased with increasing crop level, probably due to a decrease in new root tip production in the heavy crop-loaded trees (Berman and DeJong, 1996).

Trees respond differently to deficit irrigation, depending on the fruit growth stage (Behboudian and Mills, 1997). Deficit irrigation in stage I and II of fruit growth, did not affect yield (Li et al., 1989),

Received for publication 12 Mar. 1998. Accepted for publication 5 Oct. 1998. The cost of publishing this paper was defrayed in part by the payment of page charges. Under postal regulations, this paper therefore must be hereby marked advertisement solely to indicate this fact. in spite of low soil water potential, whereas deficit irrigation in stage III decreased fruit size and changed some quality attributes (Chalmers and Wilson, 1978; Li et al., 1989). Crop water consumption in stage III was much higher than that in stage II (Boland et al., 1993; Olsson, 1977) and can reach 120\% of the Class A pan evaporation rate. Trees that were irrigated at rates of 100 and $130 \%$ of Class A pan evaporation in stage III produced fruit of similar sizes (Mitchell and Chalmers, 1982). Irrigation level affects soil water availability and, thereby, plant water status, fruit yield and size (Berman and DeJong, 1996; Boland et al., 1993), and shoot growth (Chalmers et al., 1981).

Midday stem water potential may be a sensitive and rapid tool in irrigation scheduling and water stress assessment with orchard trees. Differences in midday stem water potential between trees receiving high and low irrigation treatments, were previously found to be higher than those for midday leaf water potential, in many orchard trees (Garnier and Berger, 1985; McCutchan and Shackel, 1992; Naor, 1998; Naor and Wample, 1994; Naor et al., 1995; Stern et al., 1998). Apple (Malus $\times$ domestica Borkh.) (Naor et al., 1995, 1997c) and pear (Pyrus communis L.) (Shackel et al., 1997) fruit size, almond [Prunus dulcis (Mill. D.A. Webb] trunk cross-sectional area (Shackel et al., 1997), and the percent of cherry (Prunus avium L.) growing buds were found to be correlated with midday stem water potential. The data reported in the past decade clearly indicate that midday stem water potential should be considered as a plant water stress indicator in many deciduous trees including peach and nectarine.

Berman and DeJong (1996) tested the effect of two extreme irrigation levels and three crop levels. However, their crop loads were higher and level of deficit irrigation less than those typically used in Israel. There is a need for further, more detailed study on 
Table 1. Cumulative irrigation rates in stages I + II, and in stage III of fruit growth; daily irrigation rates and crop coefficients [percentage of potential evapotranspiration rate (ETp)] in stage III of fruit growth. Numbers in parentheses are Average ETp $\left(\mathrm{mm} \cdot \mathrm{d}^{-1}\right)$ in stage III.

\begin{tabular}{|c|c|c|c|c|c|c|c|c|}
\hline \multirow[b]{2}{*}{ Treatment } & \multicolumn{2}{|c|}{$\begin{array}{l}\text { Irrigation level } \\
\text { in stage I + II } \\
(\mathrm{mm})\end{array}$} & \multicolumn{2}{|c|}{$\begin{array}{l}\text { Irrigation level } \\
\text { in stage III } \\
(\mathrm{mm})\end{array}$} & \multicolumn{2}{|c|}{$\begin{array}{l}\text { Daily irrigation } \\
\text { in stage III } \\
(\mathrm{mm})\end{array}$} & \multicolumn{2}{|c|}{$\begin{array}{l}\text { Crop coefficients } \\
\text { in stage III } \\
(\% \text { ETp })\end{array}$} \\
\hline & 1996 & 1997 & 1996 & 1997 & 1996 & 1997 & 1996 & 1997 \\
\hline & & & & & & & $(6.8)$ & (5.7) \\
\hline 1 & 257 & 380 & 204 & 123 & 4.3 & 3.8 & 0.62 & 0.62 \\
\hline 2 & 268 & 379 & 268 & 167 & 5.6 & 5.2 & 0.82 & 0.84 \\
\hline 3 & 280 & 379 & 299 & 211 & 6.2 & 6.5 & 0.92 & 1.06 \\
\hline 4 & 273 & 380 & 413 & 255 & 8.6 & 7.8 & 1.27 & 1.29 \\
\hline
\end{tabular}

the interaction between crop level and irrigation level in relation to yield, fruit size and soil and plant water status. An improved understanding of these interactions are expected when treating irrigation and crop levels and water potentials as continuous variables. The objective of the present investigation was, therefore, to study the combined effect of four irrigation levels in stage III and a wide range of crop levels, on yield, fruit size distribution, and soil and stem water potentials.

\section{Materials and Methods}

Climatic conditions. The experimental site was in the northern Galilee, Israel $\left(33^{\circ} \mathrm{N}, 36^{\circ} \mathrm{E}\right), 350 \mathrm{~m}$ above mean sea level, which is a semiarid zone with no summer rain. The average precipitation (October to April) in this area is about $550 \mathrm{~mm}$.

EXPERIMENTAL ORCHARD. The experimental plot was a 6-yearold, drip-irrigated, commercial orchard of 'Fairlane' nectarine on Prunus persica seedlings rootstock spaced $4 \times 4.5 \mathrm{~m}$ apart. The irrigation system consisted of two lateral lines per row, spaced 1.0 $\mathrm{m}$ apart, with $2.3 \mathrm{~L} \cdot \mathrm{h}^{-1}$ pressure-compensated in-line drippers, spaced $1.0 \mathrm{~m}$ apart.

Statistical DeSign. The experiment was a split plot factorial design with four irrigation levels as main plots and crop level as subplots. The treatments were replicated randomly five times. Each main plot (irrigation treatment) consisted of six adjacent rows with three trees each. The four inner trees were used for the crop level treatments.

Treatments. The experimental plot was irrigated until the end of stage II, according to commercial practice: irrigation started by the end of April at 0.33 of potential evapotranspiration (ETp), and gradually increased to 0.55 ETp at the end of stage I (beginning of June). Irrigation in stage II [beginning of June until middle (1996) or end (1997) July] was 0.62 ETp. Differential treatments were applied in stage III. Irrigation rates after harvest decreased to $0.55 \mathrm{ETp}$. The experimental plot was irrigated daily in stage III except for weekends, when a 2-d interval was used. Four irrigation levels were implemented in stage III, 0.62, 0.82, 0.92, and 1.27 of ETp in 1996, and 0.62, $0.84,1.06$, and 1.29 of ETp in 1997. The fruit on the four inner trees in each irrigation (main) plot were counted in the first week of June and hand-thinned to four fruit levels: 0 to 200, 201 to 400, 401 to 600 , and 601 to 800 fruit/tree. Fruit thinning had not been sufficiently accurate; therefore, the actual fruit levels (200 to 1200) measured at harvest were used for data analysis.

Crop measurements. The fruit from the experimental plots were harvested at the beginning of September (three selective pickings in 1996 and two in 1997, according to size (>60 mm in diameter), and color). The fruit of each tree were weighed, and their size distribution was determined by means of a commercial grading machine (50 to $85 \mathrm{~mm}$ in diameter).

SoIL WATER POTENTIAL MEASUREMENTS. Two tensiometers (Irrometer, Riverside, Calif.) were installed in each plot in mid-May, one at $50 \mathrm{~cm}$ and the other at $80 \mathrm{~cm}$ depth. The tensiometers were located close to a tree trunk, $20 \mathrm{~cm}$ from an emitter. Trees having medium crop levels were chosen for tensiometer installation. Tensiometer readings were taken in the morning, before irrigation started. In the first 3 weeks after installation, tensiometers having irregular readings were reinstalled to improve uniformity.

STEM WATER Potential MEASUREMENTS. Midday stem water potential was measured with a pressure chamber. Two shoot tips per tree were sampled from the inner part of the canopy; they were enclosed, while still attached, in plastic bags covered with aluminum foil. After an equilibrating period of $90 \mathrm{~min}$, the shoot tips were detached from the shoot, and stem water potential was determined immediately in the field with a pressure chamber (AriMad, Kfar Charuv, Golan Heights, Israel). The two measurements were averaged for statistical analysis. Stem water potential measurements were usually taken from the trees near where the tensiometers were installed. On two occasions in 1996, measure-
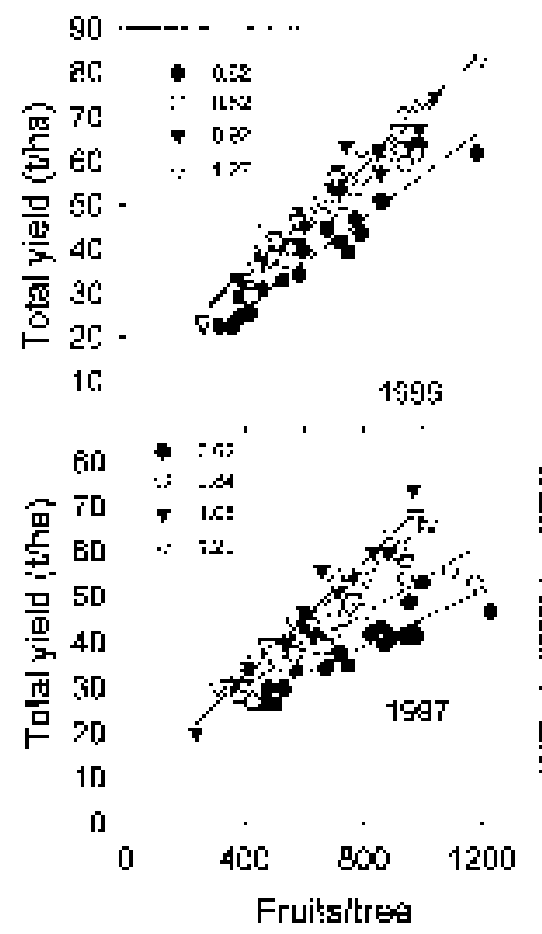
ments were taken in all crop levels of the highest and the lowest irrigation level treatments.

Statistical analySIS. The crop yield and water potential data of all crop levels and all replicates in each irrigation level treatment were pulled together, and the relationships between those variables were analyzed by linear regression, using SAS REG (SAS Institute, Cary, N.C.) procedure. All replicates in each irrigation level treatment were divided into three crop levels $(<500,500$ to 750 , and $>750$ fruit/tree). Thereafter, the effect of the three crop levels on fruit size distribution, within each fruit size

Fig. 1. Total crop yield as a function of crop level in the four irrigation treatments in 1996 and 1997. Numbers in legends are crop coefficients (percentage of potential evapotranspiration). 


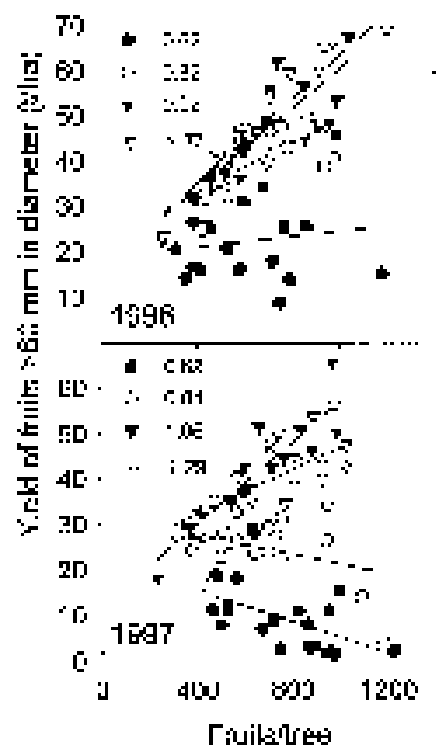

Fig. 2. Crop yield of fruit $>60 \mathrm{~mm}$ in diameter as a function of crop level in the four irrigation treatments in 1996 and 1997. Numbers in legends are crop coefficients (percentage of potential evapotranspiration).

grade in each irrigation level, was tested by analysis of variance followed by Duncan's multiple range test, using the SAS GLM(SAS Institute) procedure.

\section{Results}

IRRIGATION. Cumulative irrigation during stage III of fruit growth ranged from 204 to 413 $\mathrm{mm}$ in 1996 and from 123 to 255 mm in 1997 (Table 1). Daily irrigation rates in stage III were lower in 1997 than in 1996 (Table 1) because of the higher evaporative demand and the longer period of stage III in 1996 than in 1997.

Crop YIELD. Average crop level was similar in both years and across all irrigation treatments (606 to 768 fruit/tree). Total crop yield increased with crop level and irrigation level (Fig. 1), where differences between irrigation levels increased with increasing crop level. The yield of large fruit in the 0.62 of ETp irrigation treatment remained practically unchanged with increasing fruit level in 1996 and decreased slightly with increasing fruit level in 1997 (Fig. 2). Total yield and yield of large fruit of trees irrigated at $0.62,0.82$, and 1.27 of ETp in 1996, were more responsive to crop level (Figs. 1 and 2; Table 2) compared with the equivalent irrigation levels in 1997 (0.62, 0.84, and 1.29 of ETp). However, trees irrigated at 0.92 of ETp in 1996 had similar crop yield response to crop level compared with trees irrigated at 1.06 of ETp in 1997. This minimizes the possibility that year-to-year differences in potential fruit size accounted for the higher yield response to crop level in the other treatments in 1996.

Fruit size distribution shifted towards larger fruit sizes with increasing irrigation level (Fig. 3) in both years. However, crop level negatively influenced fruit size, as expected (Fig. 3). In 1997, fruit size distribution shifted to smaller fruit compared to 1996, and the differences between years were more pronounced at low than at high irrigation levels (Fig. 3).

WATER POTENTIALs. Soil water potential in all treatments decreased from $-20 \mathrm{kPa}$ at both 50 and $80 \mathrm{~cm}$ depths at the beginning of stage II to about $-40 \mathrm{kPa}$ at $50 \mathrm{~cm}$ and $-60 \mathrm{kPa}$ at $80 \mathrm{~cm}$ depth by the end of stage II (data not shown). Decreases in soil water potential were expected since irrigation was applied at 0.62 of ETp in stage II. Large differences in soil water potential were apparent during stage III among irrigation treatments at both depths (Fig. 4), where those differences were significant only in the $80 \mathrm{~cm}$ depth. Soil water potential fluctuated with a weekly periodicity: high soil water potentials were apparent on Mondays, after an irrigation to make up for a 2-d water loss, and thereafter soil water potential decreased through the course of the week.

Midday stem water potential increased with increasing irrigation rate, up to a 0.92 ETp in 1996 and up to 1.06 ETp in 1997 seasons (not shown). Midday stem water potential was not affected by crop level in the two extreme irrigation treatments in 1996 (Fig. $5)$. However the midday stem water potential was highly correlated with yield of large fruit (Fig. 6).

\section{Discussion}

INTERACTIONS OF CROP LOAD AND WATER POTENTIALS. OUR data show no effect of crop level on midday stem water potential in stressed trees (Fig. 5). It contradicts other studies that report a significant decrease in midday stem water potential with increas-

Table 2. Linear regression analysis of total crop yields and yields of large fruit ( $>60 \mathrm{~mm}$ in diameter) as a function of the number of fruit per tree in 1996 and 1997.

\begin{tabular}{|c|c|c|c|c|c|}
\hline Year & $\begin{array}{l}\text { Treatment } \\
(\% \text { ETp })\end{array}$ & $\begin{array}{l}\text { Yield } \\
\text { component } \\
\left(\mathrm{Mg} \cdot \mathrm{ha}^{-1}\right)\end{array}$ & Intercept & Slope & $r^{2}$ \\
\hline & & Total & & & \\
\hline \multirow[t]{5}{*}{1996} & 0.62 & & $7.1 \mathrm{a}^{\mathrm{z}}$ & $0.050 \mathrm{~b}$ & 0.94 \\
\hline & 0.82 & & $11.0 \mathrm{a}$ & $0.055 \mathrm{ab}$ & 0.95 \\
\hline & 0.92 & & $10.0 \mathrm{a}$ & $0.061 \mathrm{a}$ & 0.94 \\
\hline & 1.27 & & $10.6 \mathrm{a}$ & $0.062 \mathrm{a}$ & 0.97 \\
\hline & & $>60 \mathrm{~mm}$ in & & & \\
\hline \multirow[t]{5}{*}{1996} & 0.62 & & $18.9 \mathrm{a}$ & $0.0057 \mathrm{c}$ & 0.02 \\
\hline & 0.82 & & $23.7 \mathrm{a}$ & $0.025 \mathrm{bc}$ & 0.46 \\
\hline & 0.92 & & $16.4 \mathrm{a}$ & $0.043 \mathrm{ab}$ & 0.74 \\
\hline & 1.27 & & $16.3 \mathrm{a}$ & $0.047 \mathrm{a}$ & 0.84 \\
\hline & & Total & & & \\
\hline \multirow[t]{5}{*}{1997} & 0.62 & & $15.0 \mathrm{a}$ & $0.030 \mathrm{c}$ & 0.77 \\
\hline & 0.84 & & $14.8 \mathrm{~b}$ & $0.039 \mathrm{c}$ & 0.88 \\
\hline & 1.06 & & $7.5 \mathrm{a}$ & $0.063 \mathrm{a}$ & 0.95 \\
\hline & 1.29 & & $13.7 \mathrm{a}$ & $0.052 \mathrm{~b}$ & 0.94 \\
\hline & & $>60 \mathrm{~mm}$ in & & & \\
\hline \multirow[t]{4}{*}{1997} & 0.62 & & $22.5 \mathrm{a}$ & $-0.17 \mathrm{c}$ & 0.28 \\
\hline & 0.84 & & $32.0 \mathrm{~b}$ & $-0.01 \mathrm{c}$ & 0.11 \\
\hline & 1.06 & & $11.8 \mathrm{a}$ & $0.045 \mathrm{a}$ & 0.78 \\
\hline & 1.29 & & $22.4 \mathrm{a}$ & $0.025 \mathrm{~b}$ & 0.44 \\
\hline
\end{tabular}

${ }^{\mathrm{z}}$ Results followed by different letters differ significantly, $p=0.05$ 

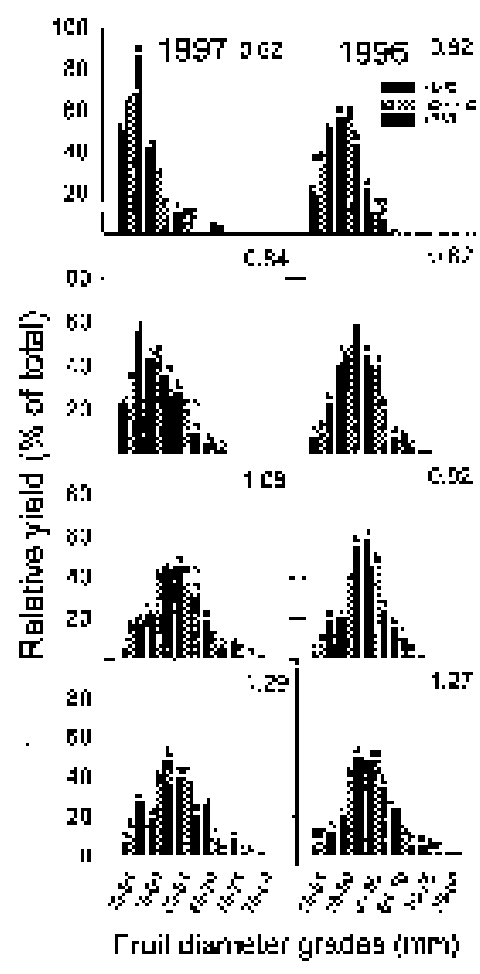

Fig. 3. Fruit size distribution in 1996(righthand figures) and 1997 (left-hand figures) in the four irrigation treatments (numbers in three crop levels in each of the upper right-hand corners are crop coefficients (percentage of potential evapotranspiration). Results within each fruit diameter grade followed by different letters differ significantly, $p=0.05$.

Numbers in legends are fruit per tree.

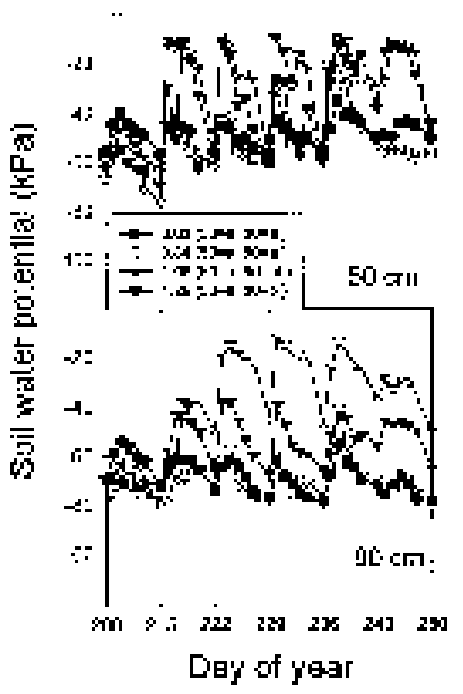

Fig. 4. Morning soil water potentials before irrigation 1.5 months before harvest in 1997, in the four irrigation treatments. Numbers in legends are crop coefficients (percentage of potential evapotranspiration). Results within each soil depth followed by different letters differ significantly, $p=0.05$. Statistical analysis was performed on the average soil water potential from DOY 215 up to harvest (DOY 243)

ing crop level in stressed peach (Berman and DeJong, 1996) and apple (Naor et al., 1997c). A question is raised, why midday stem water potential in the current study, responds differently to increasing crop level compared to that reported by Berman and DeJong (1996). Although number of fruit per hectare was similar to that reported by Berman and DeJong (1996), we observed a linear yield response to crop level (Fig. 1) compared with a nonlinear yield response to crop level by Berman and DeJong (1996). This suggests that the crop load (fruit per unit of leaf area, or light interception) was smaller in our study. It seems therefore that stem water potential of stressed trees is dependent on both the number of fruit per hectare and the crop load. In addition, it was previously pointed out by DeJong (1986a) and Naor et al. (1997a) that differences in plant water stress, attributable to differences in climatic conditions among the various studies, may explain the contradictory findings on the effect of crop load on plant water potential.

Stem Water Potential AND YiELD. The correlation of yield with stem water potential was better than that with soil water potential (data not shown), which is consistent with previous reports for apple (Naor et al., 1995). The high (typical) variability in tensiometer readings (Fig. 4), may account for this lower correlation. The high correlation of midday stem water potential with yield (Fig. 6) is consistent with other studies on apple (Naor et al., 1995, 1997c) and pear (Shackel et al., 1997). Also, midday stem water potentials were found to be correlated with trunk cross-sectional area in almond (Shackel et al., 1997), with the fraction of growing buds in cherry (Shackel et al., 1997), and with stomatal conductance in apple, grape (Vitis vinifera L.), and nectarine (Naor, 1998). These observations clearly indicate that midday stem water potential is a

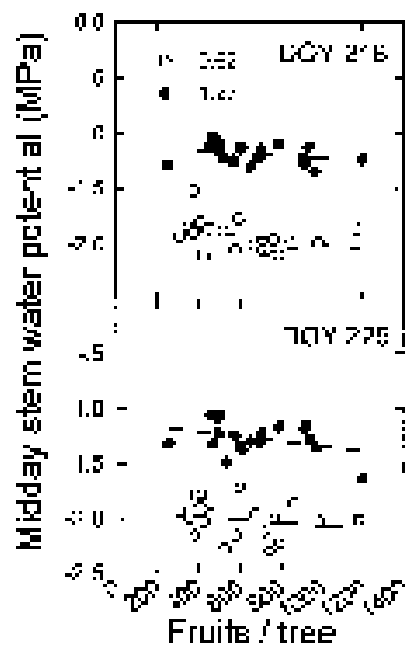

Fig. 5. Midday stem water potentials in the highest and lowest irrigation treatments on $2 \mathrm{~d}$ selected in 1996, as a function of crop level. Numbers in legends are crop coefficients (percentage of potential evapotranspiration).

useful index of tree stress and may be considered as an irrigation control criterion.

IRRIGATION SCHEDULING AND MONITORING. TOtal yield and yield of large fruit of trees irrigated at $0.62,0.82$, and 1.27 of ETp in 1996, were more responsive to crop level (Figs. 1 and 2; Table 2) compared with the equivalent irrigation levels in 1997 (0.62, 0.84, and 1.29 of ETp). These may indicate a cumulative damage to tree production in those irrigation treatments, especially in the two lower ones (Table 2). The 1.06 ETp irrigation level had the highest yield in 1997 (Table 2; Figs. 1 and 2), indicating that irrigation rate should not increase above 1.06 ETp in stage III, which is consistent with previous findings (Klein, 1983; Mitchell and Chalmers, 1982).

Midday stem water potential of the highest irrigation level was much lower than values reported for peach (Berman and DeJong, 1996), and lower than those reported for nonstressed prune (Prunus $\times$ domestica L.), almond, and cherry (McCutchan and Shackel, 1992; Shackel et al., 1997). The lower midday stem water potentials found here are probably related to the low irrigation level in stage II, which differ from other reports. Deficit irrigation in stage II may have caused depletion of water through much of the root zone, which was not restored during stage III. Nevertheless, fruit yield (Fig. 1 and 2) and midday stem water potential did not respond to increasing irrigation

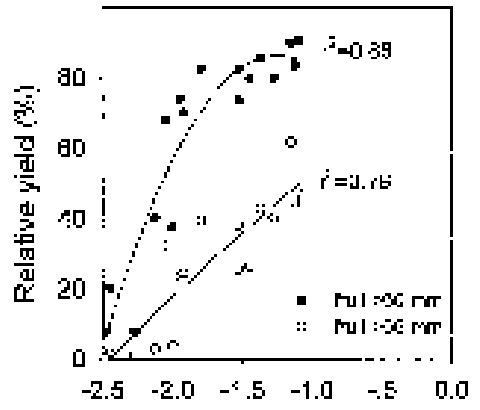

Midday stem water potential (MPa)

Fig. 6. Relative yield (percentage of total) of fruit $>60$ and $>65 \mathrm{~mm}$ in diameter in the first picking, as a function of midday stem water potential on 27 Aug. 1997. and crop load effects on fruit fresh and dry weights in peach (Prunus persica). Tree Physiol. 16:859-864.

Blanco, A., A. Pequerul, J. Val, E. Monge, and J. Gomez-Aparisi. 1995. Crop-load effects on vegetative growth, mineral nutrient concentration and leaf water potential in Catherine peach. J. Hort. Sci. 70:623-629. 
Boland, A., P.D. Mitchell, P.H. Jerie, and I. Godwin. 1993. The effect of regulated deficit irrigation on tree water use and growth of peach. J. Hort. Sci. 68:261-274.

Chalmers, D.J. and B. van den Ende. 1975. Productivity of peach trees: Factors affecting dry-weight distribution during tree growth. Ann. Bot. (London) 39:423-432.

Chalmers, D.J. and I.B. Wilson. 1978. Productivity of peach trees: Tree growth and water stress in relation to fruit growth and assimilate demand. Ann. Bot. (London) 42:285-294.

Chalmers, D.J., R.L. Canterford, P.H. Jerie, T.R. Jones, and T.D. Ugalde. 1975. Photosynthesis in relation to growth and distribution of fruits in peach trees. Austral. J. Plant Physiol. 2:635-645.

Chalmers, D.J., P.D. Mitchell, and L. van Heek. 1981. Control of peach tree growth and productivity by regulated water supply, tree density and summer pruning. J. Amer. Soc. Hort. Sci. 1106:307-312.

Chalmers, D.J., K.A. Olsson, and T.R. Jones. 1983. Water relations of peach trees orchards, p. 197-232. In: T.T. Kozlowski (ed.). Water deficit and plant growth. vol 6. Academic Press, London.

Crews, C.E., S.L. Williams, and H.M. Vines, 1975. Characteristics of photosynthesis in peach leaves. Planta 126:97-104.

DeJong, T.M. 1986a. Effects of reproductive and vegetative sink activity on leaf conductance and water potential in Prunus persica (L) Batsch. Scientia Hort. 29:131-137.

DeJong, T.M. 1986b. Fruit effects on photosynthesis in Prunus persica. Physol. Plant. 66:149-153.

Garnier, E. and A. Berger. 1985. Testing water potential in peach trees as an indicator of water stress. J. Hort. Sci. 60:47-56.

Klein, I. 1983. Drip irrigation based on soil matric potential conserves water in peach and grape. HortScience 18:942-944.

Li, S.H., J.G. Huguet, P.G. Schoch, and P. Orlando. 1989. Responses of peach tree growth and cropping to soil water deficit at various phenological stages of fruit development. J. Hort. Sci. 64:541-552.

McCutchan, H. and K.A. Shackel. 1992. Stem-water potential as a sensitive indicator of water stress in prune trees (Prunus domestica L.cv. French). J. Amer. Soc. Hort. Sci. 117:607-611.

Mitchell, P.D. and D.J. Chalmers. 1982. The effect of reduced water supply on peach tree growth and yields. J. Amer. Soc. Hort. Sci.
107:853-856.

Naor, A. 1998. Relationships between leaf and stem water potentials and stomatal conductance in three field-grown woody species. J. Hort. Sci. (in press).

Naor, A. and R. L. Wample. 1994. Gas exchange and water relations of field-grown Concord (Vitis labrusca) grapevines. Amer. J. Enol. Viticult. 45:333-337.

Naor, A., I. Klein, and I. Doron. 1995. Stem water potential and apple fruit size. J. Amer. Soc. Hort. Sci. 120:577-582.

Naor, A., Y. Gal, and B. Bravdo. 1997a. Crop load affects assimilation rate, stomatal conductance, stem water potential and water relations of field-grown Sauvignon blanc grapevines. J. Expt. Bot. 314:1675-1680.

Naor, A., I. Klein, I. Doron, Y. Gal, Z. Ben-David, and B. Bravdo. 1997b. Irrigation and crop load interactions in relation to apple yield and fruit size distribution. J. Amer. Soc. Hort. Sci. 122:411-414.

Naor, A., I. Klein, I. Doron, Y. Gal, Z. Ben-David, and B. Bravdo. 1997c. The effect of irrigation and crop load on stem water potential and apple fruit size. J. Hort. Sci. 72:765-771.

Olsson, K.A. 1977. Physical aspects of the water relations of an irrigated peach orchard. PhD thesis, Macquarie Univ., Sydney, Australia.

Rowe, R.N. and R. Johnson. 1992. The interactions between fruit number, tree size and the yield and fruit size of Fantasia nectarine. Acta Hort. 315:171-176.

Shackel, K.A., H. Ahmadi, W. Biasi, R. Buchner, D. Goldhamer, S. Gurusinghe, J. Hasey, D. Kester, B. Krueger, BB. Lampinen, G. McGourty, W. Micke, E. Mitcham, B. Olsen, K. Pelletrau, H. Philips, D. Ramos, L. Scheankl, S. Sibbert, R. Snyder, S. Southwick, M. Stevenson, M. Thorpe, S. Weinbaum, and J. Yeager. 1997. Plant water status as an index of irrigation need in deciduous fruit trees. HortTechnology 7:2329.

Stern R., M. Meron, A. Naor, S. Gazit, B. Bravdo, and R. Wallach. 1998. Effect of autumnal irrigation level in 'Mauritius' lychee on soil and plant water status and following year flowering intensity and yield. J. Amer. Soc. Hort. Sci. 123:150-155.

Tukey, H.B. and O. Einset. 1938. Effect of fruit thinning on size, color and yield of peaches and on growth and blossoming of the tree. Proc. Amer. Soc. Hort. Sci. 36:314-319. 